Journal of Agricultural Sciences
(Tarim Bilimleri Dergisi)

\title{
Determination of Germination Threshold Value of Chickpea Varieties with GGE Biplot Method Under Different Irrigation Water Salinity Conditions
}

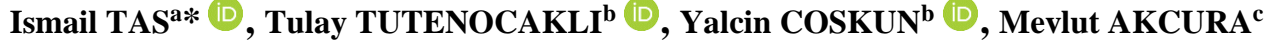 \\ ${ }^{a}$ Department of Agricultural Structures and Irrigation, Agriculture Faculty, Canakkale Onsekiz Mart University, Canakkale, TÜRKIYYE \\ ${ }^{b}$ Lapseki Vocational College, Canakkale Onsekiz Mart University, Canakkale, TÜRKIYYE \\ ${ }^{c}$ Department of Field Crops, Agri. Faculty, Canakkale Onsekiz Mart University, Canakkale, TÜRKIYE
}

\section{ARTICLE INFO}

Research Article

Corresponding Author: Ismail TAS, E-mail: tas_ismail@yahoo.com

Received: 8 February 2021; Revised: 3 December 2021, Accepted: 5 December 2021 / Online: 15 October 2022

Cite this article

TAS I, TUTENOCAKLI T, COSKUN Y, AKCURA M (2022). Determination of Germination Threshold Value of Chickpea Varieties with GGE Biplot Method Under Different Irrigation Water Salinity Conditions. Journal of Agricultural Sciences (Tarim Bilimleri Dergisi), 28(4):711-722. DOI: 10.15832/ankutbd.876362

\section{ABSTRACT}

For sustainable agricultural production, besides drought, plant resistance to irrigation water and soil salinity should be investigated. Researchers mostly focused on salinity and drought resistance of common species such as wheat, barley, maize, etc. However, the number of studies on chickpea with various uses is quite limited. In the present study, 11 chickpea varieties (Aksu, Arda, Hasanbey, Azkan, Cagatay, Aslanbey, Inci, Seckin, 21C, 42C and EN1867) were subjected to germination tests under different levels of irrigation water salinity (ECi) conditions to identify irrigation water salinity resistant and sensitive varieties. In germination tests, besides control treatment $(0 \mathrm{dS} / \mathrm{m})$, five different EC levels $(6,810,12$ and $16 \mathrm{dS} / \mathrm{m})$ were used in germination solution. The sodium absorption ratio of saline waters was adjusted to be below 3 . GGE biplot method was used for visual assessment of genotype response to saline irrigation waters. The threshold salinity value for germination was identified as $12 \mathrm{dS} / \mathrm{m}$ based on germination ratios and seedling dry weights, $8 \mathrm{dS} / \mathrm{m}$ based on seedling stem lengths and $10 \mathrm{dS} / \mathrm{m}$ based on seedling root lengths. Based on germination ratios and seedling dry weights, Azkan cultivar was identified as the most resistant and Cagatay cultivar was identified as the most sensitive cultivar to irrigation water salinity.

Keywords: Irrigation water quality, Germination ratios, Total salinity

\section{Introduction}

Chickpea is used in human nutrition and animal feeding in various parts of the world. Chickpea kernels are quite rich in protein, so constitute a good source of nutrient. Chickpea straw is a valuable forage source. Chickpea does not require too much water during the growing period and therefore it is considered as a drought-resistant plant. The drought level increases with the effect of the increasing global warming from year to year, and chickpea becomes advantageous compared to many other plant species. Together with increasing populations and rapid economic growth, water shortage has become a fundamental and chronic problem for sustainable agriculture especially in arid and semi-arid regions. Meanwhile, irrigation water quality is continuously deteriorated (Jiang et al. 2012). Water deficits in arid and semi-arid regions have made the use of saline water an inevitable component of irrigations (Assouline et al. 2006; Letey et al. 2007). However, the use of saline or brackish water increases the risk of soil salinization due to salt accumulation within the root zone (Pereira et al. 2002; Min et al. 2014).

Because saline water is among the most limiting factors in agriculture, it is important to study the potential effects of salt stress on plant growth and yield (Sozen \& Karadavut 2018; Yurtseven et al. 2018). Soil salinity induces osmotic stress by increasing both the accumulation of toxic concentration of $\mathrm{Na}$ and $\mathrm{Cl}$ ions and the prevention of uptake of essential nutrients such as K, Ca and $\mathrm{NO}_{3}$ (Munns 2002; Okhovatian-Ardakani et al. 2010; Peykanpour et al. 2016). Such negative impacts of salinity then alter soil flora and fauna, impairs germination and mergence and ultimately reduce yield and quality. In sustainable agriculture, the primary target is to supply optimum conditions to plants from seeding to harvest without generating any environmental problems. Natural supply of sufficient quantity and quality irrigation water is getting more difficult every day and water quality has become more important problem than water supply. Increasing pollution factors reduce water quality and use of low-quality waters has become an essential issue in irrigations. Such low-quality waters then result in soil salinity and reduce available land resources.

Irrigation water is the primary source of salts accumulated in soils. Inappropriate irrigation water quality directly influences fertilizer uptake from the soil. Plant nutrient uptake through root system depends on nutrient concentrations in soil. In case of 
use of low-quality irrigation waters, plant characteristics should be taken into consideration. Both irrigation water pollution and increasing soil salinity in agricultural lands are the most important limiting factors for cultivation of culture crops. To meet increasing needs, marginal waters should be used and agricultural lands should be used for production. Saline lands could also be used in production through the use of salt-resistant plants.

Salinity studies generally are not conducted under field conditions since i) precipitation and groundwater levels are not able to be controlled, ii) soil salinity vary vertically and horizontally in short distances, salt concentrations and soil characteristics may also varies, iii) plant salt uptake and sensitivity may vary with the species and the environmental conditions (light intensity, temperature, relative humidity). Such studies should be conducted in multi replicates, thus require quite large areas and discordant results are obtained in most cases. Just because of these difficulties, generally more practical and reliable greenhouse and laboratory experiments are conducted. However, outcomes of such studies under controlled conditions should be proved under field conditions, then appropriate selection methods should be offered to breeders (Yeo et al. 1990; Ekiz et al. 2000; Koyuncu 2008).

Biplot was developed for the first time by Gabriel (1971) to present significant traits of a data matrix. Then, biplot started to be applied in various disciplines and proved to be highly practical method in visual presentation of experimental data. Biplot method was used in biomedical researches (Gabriel \& Odoroff 1990), in multivariate process data (Sparks et al. 1997), two-way cross tables (Bradu \& Gabriel 1978, Gabriel 1995), robust methods (Daigle \& Rivest 1992), growth curve analysis (Ojeda \& Juarez-Cerrillo 1996) and suitability analysis (Greenacre 1984; 1993).

Yan (2014) indicated that GGE Biplot analysis method could be used in analysis of all two-way data, in identification of which genotype is well adapted to which environment and which genotypes yielded better outcomes in all environments. Different genetic variation sources should be investigated with the use of developed methods and selection criteria should be developed in breeding programs. Genotypic/cultivar differences in germination play an important role in identification of salt resistance (Saxena et al. 1994). In this sense, seed germination in saline media in petri dishes is largely used to determine salt resistance rapidly (Jana \& Slinkard 1976). Salt tolerance of beans (Goertz \& Coons, 1989; Guvenc \& Kantar 1996; Elkoca \& Kantar 2003), sorghum (Esechie 1994), bread wheat (Kirtok et al. 1994; Coskun \& Tas 2017) and different vegetables (Cucci et al. 1994) were tested in petri dishes with different salt solutions. Germination test results should be proven with small plot and field experiments.

In present study, different chickpea varieties were subjected to germination tests under saline irrigation water conditions to identify irrigation water salinity resistant and sensitive varieties. It is expected that the present results will provide important contributions for the breeding of chickpea varieties resistant to irrigation water salinity.

\section{Material and Methods}

Eleven chickpea cultivars commonly cultivated in Turkey were selected as the plant material of the study (Table 1). Experiments were conducted in randomized blocks - split plots experimental design with 3 replicates in laboratories of Canakkale Onsekiz Mart University Faculty of Agriculture. Pre-tests were conducted with randomly selected cultivars and germination threshold salinity level was determined as $10 \mathrm{dS} / \mathrm{m}$. Present treatments were selected as two levels below and two levels above this threshold.

Table 1- Chickpea genotypes used in this study

\begin{tabular}{cc}
\hline Genotype No & Cultivar name \\
\hline G1 & Aksu \\
G2 & Arda \\
G3 & Hasanbey \\
G4 & Azkan \\
G5 & Cagatay \\
G6 & Aslanbey \\
G7 & Inci \\
G8 & Seckin \\
G9 & $21 \mathrm{C}$ \\
G10 & $42 \mathrm{C}$ \\
G11 & EN1867 \\
\hline
\end{tabular}

Besides the control treatment, irrigation waters were prepared at 6, 8, 10, 12 and $16 \mathrm{dS} / \mathrm{m}$ electrical conductivity (ECi), SAR was adjusted to be below 3. Different salt sources $(\mathrm{Na}, \mathrm{Ca}$ and $\mathrm{Mg}$ ) were used to prepare saline irrigation waters. Ca/Mg ratio was adjusted to be greater than 2. Twenty seeds of each cultivar were placed into $15 \mathrm{~cm}$ diameter petri dishes. Petri dishes were supplemented with $45 \mathrm{~mL}$ of saline germination water. Seeded Petri dishes were monitored for 7 days. Along with the recommendations of Wang et al. (2009) and Kusvuran (2015), seeds were considered as germinated when the rootlets were 
emerged. Germinated seeds were dried in an oven at $60{ }^{\circ} \mathrm{C}$ for 48 hours and weighed to get dry weights. Germinated seeds of each petri dish were converted into percentage to get germination ratios as recommended by Atak et al. (2006).

Descriptive statistics was used to determine germination ratio, root length, stem length and seedling dry weights. Regression and GGE biplot graphs were used for visual presentation of the experimental data (Alkan 2011). GGE biplot method was used to identify the best genotypes at each salinity level, the genotypes tolerant to entire salinity levels and germination threshold salinity level of the genotypes. In GGE biplot analysis of genotype x environment interactions, irrigation water salinity levels were considered as environments. GGE biplot graphs were generated with different perspectives (Yan 2014).

\section{Results and Discussion}

\subsection{Germination ratio}

Decreasing germination ratios were observed with increasing irrigation water salinity levels (Table 2). Except for one genotype (G8), germination was observed in all genotypes at $16 \mathrm{dS} / \mathrm{m}$ ECi level. Regression graphs for changes in germination ratios of the genotypes based on ECi levels are presented in Figure 1a and Genotype - ECi Biplot graph indicating which genotype had the greatest germination ratio at which $\mathrm{ECi}$ level and which genotype had the greatest germination ratio at all ECi levels is presented in Figure 1b. As can be seen in Figure1a, germination ratios linearly decreased with increasing ECi levels. However, genotypes G5 and G8 had greater decreases as compared to the other genotypes.

Table 2- Change in germination ratios of chickpea geneotype with ECi levels

\begin{tabular}{ccccccc}
\hline Genotype & $0 d S / m$ & $6 d S / m$ & $8 d S / m$ & $10 d S / m$ & $12 d S / m$ & $16 d S / m$ \\
\hline G1 & $73.01 \pm 15.06$ & $62.23 \pm 7.15$ & $58.83 \pm 7.09$ & $52.70 \pm 6.45$ & $37.85 \pm 14.27$ & $25.58 \pm 4.57$ \\
G2 & $75.30 \pm 12.51$ & $71.79 \pm 12.31$ & $58.00 \pm 12.59$ & $51.47 \pm 8.47$ & $44.45 \pm 7.14$ & $12.58 \pm 5.84$ \\
G3 & $71.72 \pm 12.63$ & $58.62 \pm 4.74$ & $52.45 \pm 2.40$ & $47.69 \pm 2.24$ & $44.85 \pm 5.71$ & $28.49 \pm 7.93$ \\
G4 & $76.21 \pm 5.59$ & $66.87 \pm 0.18$ & $64.31 \pm 3.73$ & $62.32 \pm 2.16$ & $52.91 \pm 6.63$ & $39.58 \pm 5.79$ \\
G5 & $39.03 \pm 8.39$ & $29.93 \pm 4.32$ & $17.50 \pm 3.81$ & $16.20 \pm 3.58$ & $12.68 \pm 2.92$ & $8.86 \pm 4.47$ \\
G6 & $54.85 \pm 1.97$ & $48.62 \pm 6.21$ & $38.32 \pm 4.32$ & $35.03 \pm 7.27$ & $24.10 \pm 13.37$ & $14.23 \pm 3.69$ \\
G7 & $67.73 \pm 3.10$ & $53.57 \pm 15.08$ & $47.17 \pm 10.54$ & $37.87 \pm 4.41$ & $31.03 \pm 7.08$ & $20.40 \pm 0.87$ \\
G8 & $21.99 \pm 4.42$ & $18.44 \pm 5.89$ & $17.72 \pm 5.17$ & $13.21 \pm 4.67$ & $12.55 \pm 5.09$ & $0.00 \pm 0.00$ \\
G9 & $47.53 \pm 6.19$ & $42.56 \pm 4.46$ & $39.03 \pm 2.64$ & $31.87 \pm 5.62$ & $28.96 \pm 5.54$ & $5.64 \pm 1.37$ \\
G10 & $76.19 \pm 6.68$ & $69.81 \pm 12.73$ & $67.18 \pm 13.05$ & $61.08 \pm 10.24$ & $43.78 \pm 5.32$ & $19.32 \pm 21.39$ \\
G11 & $41.05 \pm 1.78$ & $40.83 \pm 1.87$ & $33.33 \pm 8.94$ & $31.08 \pm 10.56$ & $22.86 \pm 11.67$ & $6.70 \pm 0.75$ \\
Genotype & $* *$ & $* *$ & $* *$ & $* *$ & $* *$ & $* *$ \\
Average & 58.60 & 51.21 & 44.89 & 40.05 & 32.37 & 16.49 \\
Minimum & 21.99 & 18.44 & 17.50 & 13.21 & 12.55 & 0.00 \\
Maximum & 76.21 & 71.79 & 67.18 & 62.32 & 52.91 & 39.58 \\
LSD 0.01 & 19.18 & 18.75 & 17.78 & 15.17 & 19.50 & 17.64 \\
\hline
\end{tabular}

**: Genotypes are statistically different $(\mathrm{P}<0.01)$ 

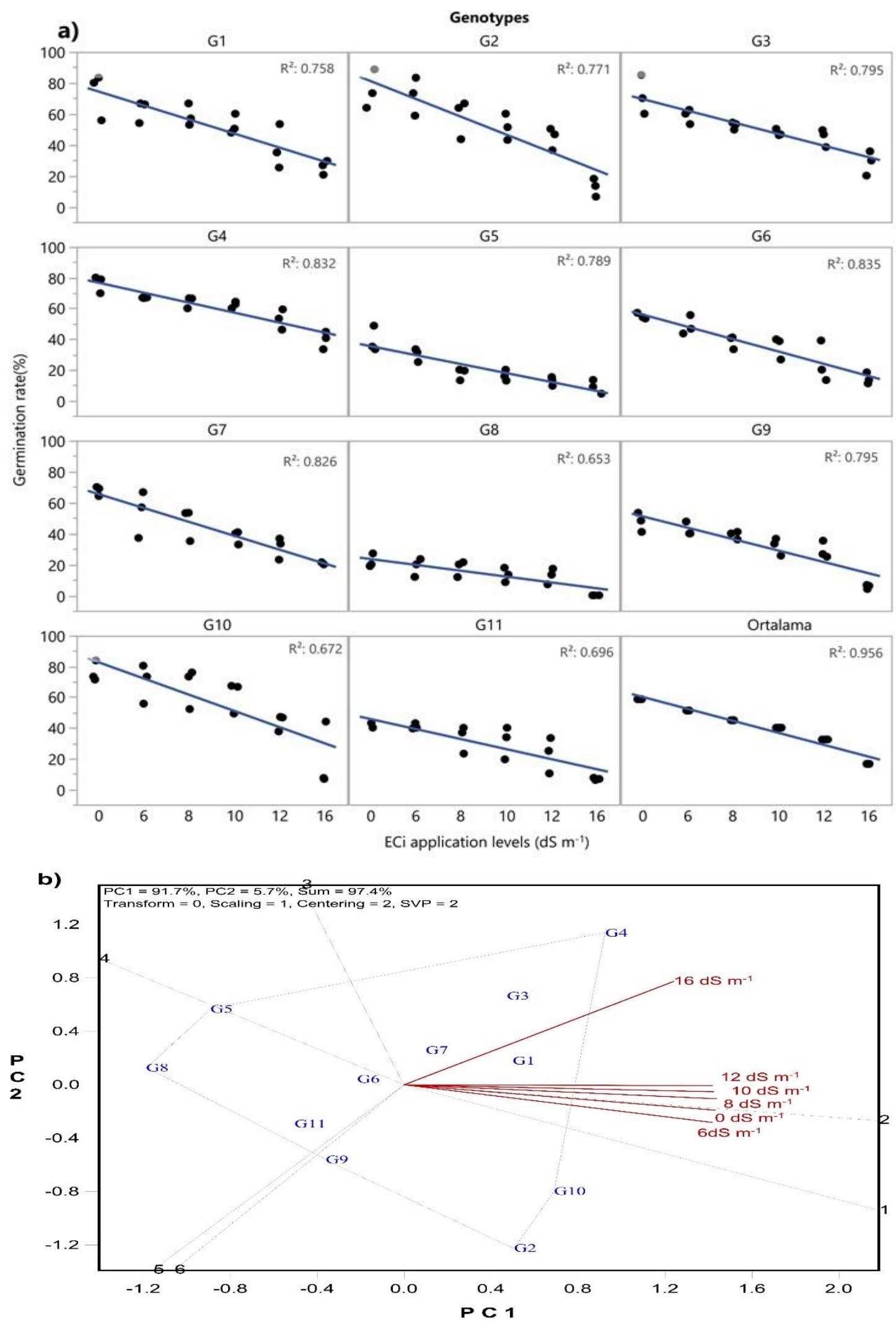

Figure 1- Germination ratios at different ECi levels a) regression b) GGE biplot graph

These genotypes also had quite lower germination ratios than the others in control treatments. Germination ratio of G5 and G8 genotypes in control treatments varied between $39.03-21.99 \%$. These values were lower than the germination ratios of the other genotypes at different ECi levels.

A biplot graph was generated for visual presentation of change in germination ratios of the genotypes with ECi levels. In this graph (Figure 1b), salt treatments were gathered under two groups. The first group included 0 and $6 \mathrm{dS} / \mathrm{m} \mathrm{ECi} \mathrm{levels} \mathrm{and} \mathrm{the}$ second group included 8, 10,12 and $16 \mathrm{dS} / \mathrm{m}$ ECi levels. However, $16 \mathrm{dS} / \mathrm{m}$ ECi level had weak correlations with the other 
levels. In other words, in terms of germination ratio, genotype response was quite distinctive in $16 \mathrm{dS} / \mathrm{m}$ treatments. In terms of germination ratio, the diagonal genotype $\mathrm{G} 4$ of the second group $(8,10,12$ and $16 \mathrm{dS} / \mathrm{m} \mathrm{ECi}), \mathrm{G} 1$, G7, G3 genotypes of this group and G10 genotype with the closest position to the first group $(6,0 \mathrm{dS} / \mathrm{m})$ were found to be superior over the others. In terms of germination ratio, the genotype G5, G8 and G9 had the most negative response to salinity (Figure 1b).

\subsection{Seedling root length}

Decreasing seedling root lengths were observed with increasing irrigation water salinity levels (Table 3). Regression graphs for changes in seedling root lengths of the genotypes with ECi levels are presented in Figure 2a. GGE biplot graph indicating the genotypes with the greatest seedling root length at each salinity level and the genotype with the greatest seedling root length at all ECi levels is presented in Figure 2b. A biplot graph was generated for visual presentation of change in seedling root lengths of the genotypes with ECi levels. In this graph, salt treatments were gathered under two groups. The first group included 0,6 and $8 \mathrm{dS} / \mathrm{m}$ ECi levels and the second group included 10,12 and $16 \mathrm{dS} / \mathrm{m}$ ECi levels.

However, 12 and $16 \mathrm{dS} / \mathrm{m}$ treatments of the second group were placed at further position to $10 \mathrm{dS} / \mathrm{m}$ treatment. In these treatments, the greatest seedling root length was observed in G9 genotype. In the first group $(0,6,8 \mathrm{dS} / \mathrm{m})$, the greatest root length was observed in G2 and G4 genotypes. In terms of root lengths, the genotype G5 and G1 had the most negative response to salinity (Figure $2 b$ ).

Table 3- Change in seedling root lengths of chickpea genotype with ECi levels

\begin{tabular}{ccccccc}
\hline Genotype & $0 d S / m$ & $6 d S / m$ & $8 d S / m$ & $10 d S / m$ & $12 d S / m$ & $16 d S / m$ \\
\hline G1 & $36.58 \pm 7.88$ & $20.81 \pm 5.33$ & $17.87 \pm 7.08$ & $13.30 \pm 5.86$ & $1.63 \pm 0.56$ & $1.86 \pm 0.81$ \\
G2 & $65.99 \pm 10.80$ & $49.67 \pm 23.79$ & $33.77 \pm 3.39$ & $22.51 \pm 13.32$ & $2.22 \pm 0.29$ & $1.63 \pm 0.56$ \\
G3 & $54.65 \pm 4.52$ & $46.24 \pm 6.68$ & $32.48 \pm 3.60$ & $8.32 \pm 1.09$ & $0.00 \pm 0.00$ & $0.00 \pm 0.00$ \\
G4 & $59.35 \pm 6.25$ & $47.61 \pm 8.66$ & $23.72 \pm 16.16$ & $21.46 \pm 1.24$ & $0.97 \pm 0.04$ & $0.00 \pm 0.00$ \\
G5 & $28.10 \pm 5.74$ & $19.52 \pm 3.77$ & $12.89 \pm 3.69$ & $11.55 \pm 4.28$ & $3.93 \pm 2.05$ & $0.00 \pm 0.00$ \\
G6 & $53.50 \pm 8.92$ & $44.11 \pm 9.74$ & $30.84 \pm 15.37$ & $6.46 \pm 1.00$ & $0.00 \pm 0.00$ & $0.00 \pm 0.00$ \\
G7 & $50.23 \pm 0.55$ & $43.83 \pm 1.62$ & $28.10 \pm 2.97$ & $11.73 \pm 6.17$ & $0.00 \pm 0.00$ & $0.00 \pm 0.00$ \\
G8 & $53.95 \pm 3.11$ & $35.81 \pm 4.33$ & $21.37 \pm 7.16$ & $15.36 \pm 7.32$ & $0.00 \pm 0.00$ & $0.00 \pm 0.00$ \\
G9 & $59.31 \pm 5.89$ & $47.28 \pm 11.78$ & $32.30 \pm 12.69$ & $18.87 \pm 14.81$ & $11.43 \pm 14.28$ & $2.55 \pm 3.47$ \\
G10 & $43.60 \pm 3.40$ & $25.61 \pm 1.61$ & $16.90 \pm 2.64$ & $14.10 \pm 0.60$ & $2.38 \pm 0.54$ & $0.00 \pm 0.00$ \\
G11 & $44.06 \pm 6.95$ & $26.14 \pm 8.15$ & $15.39 \pm 9.99$ & $8.83 \pm 4.90$ & $5.54 \pm 6.55$ & $0.00 \pm 0.00$ \\
Genotype & $* *$ & $* *$ & $* *$ & $* *$ & $* *$ & $* *$ \\
Average & 49.94 & 36.97 & 24.15 & 13.86 & 2.55 & 0.40 \\
Minimum & 28.10 & 19.52 & 12.89 & 6.46 & 0.00 & 0.00 \\
Maximum & 65.99 & 49.67 & 33.77 & 22.51 & 11.40 & 2.55 \\
LSD 0.01 & 14.81 & 22.51 & 20.97 & 16.56 & 11.01 & 2.47 \\
\hline
\end{tabular}

**: Genotypes are statistically different $(\mathrm{P}<0.01)$

\subsection{Seedling stem length}

Decreasing seedling stem lengths were observed with increasing irrigation water salinity levels (Table 4). Regression graphs for changes in seedling stem lengths of the genotypes based on ECi levels are presented in Figure 3a and Genotype - ECi Biplot graph indicating which genotype had the greatest seedling stem length at which ECi level and which genotype had the greatest seedling stem length at all ECi levels is presented in Figure 3b. In this graph, salt treatments were gathered under three groups.

The first group included 0, 6 and $8 \mathrm{dS} / \mathrm{m}$ ECi levels, the second group included 10 and $12 \mathrm{dS} / \mathrm{m}$ ECi levels and the third group included $16 \mathrm{dS} / \mathrm{m}$ ECi level. In the first group, the greatest stem length was observed in G2 and G6 genotypes. In the second group, G9 and G4 genotypes were prominent for stem lengths. These genotypes were placed at diagonals. The $16 \mathrm{dS} / \mathrm{m}$ ECi treatment constituting the third group alone had the lowest vector length. In this treatment, stem lengths of the genotypes were quite low and the greatest values were observed in G10 and G5 genotypes (Figure 3b). 

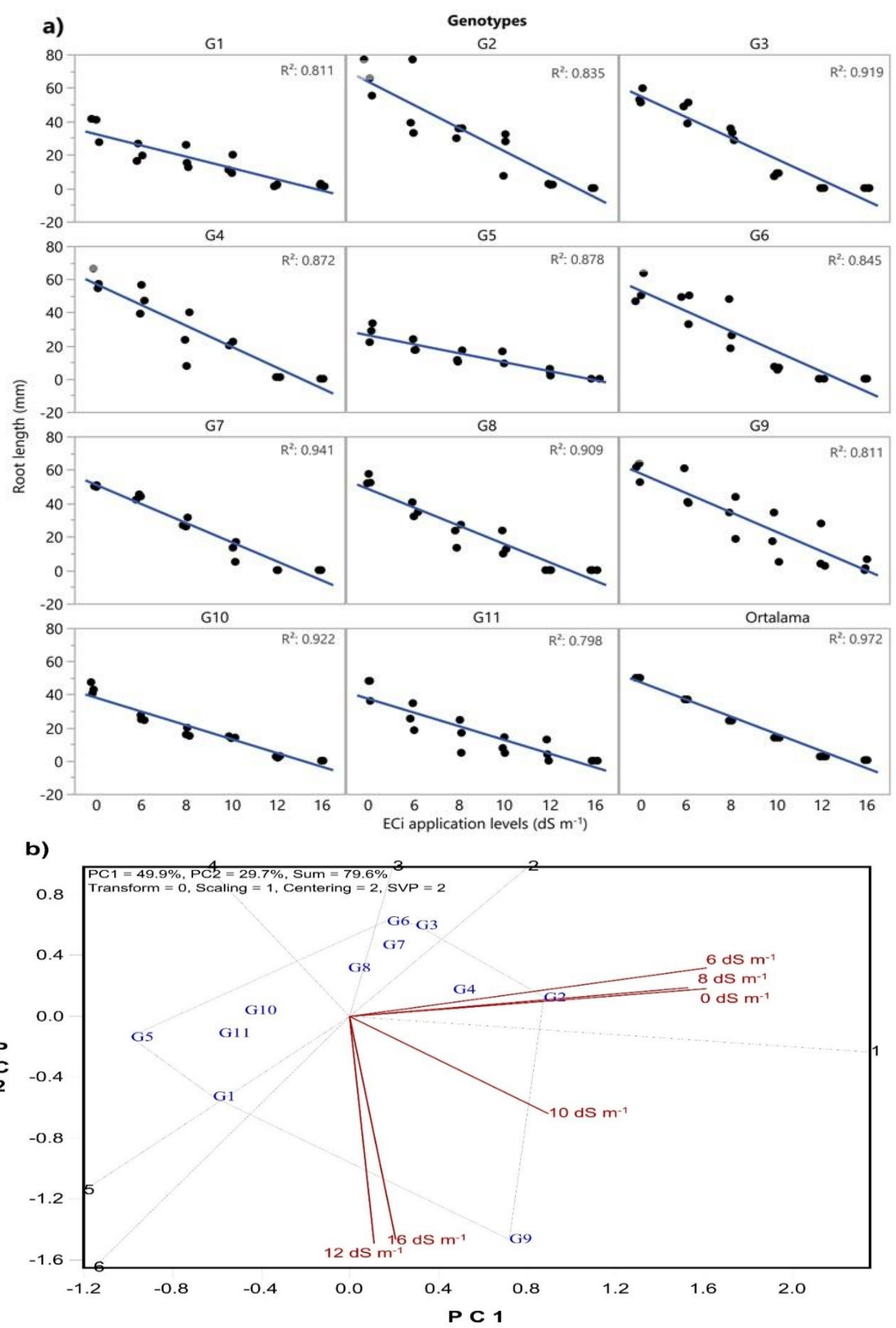

Figure 2- Seedling root lengths at different ECi levels a) regression b) GGE biplot graph

However, in the second group, diagonal ECi levels of 12 and $16 \mathrm{dS} / \mathrm{m}$ were placed at further position to $10 \mathrm{dS} / \mathrm{m}$ treatment. The greatest stem length in these treatments was observed in G9 genotype. In the first group $(0,6,8 \mathrm{dS} / \mathrm{m})$, the greatest seedling stem length was observed in G2 and G4 genotypes. In terms of stem lengths, the genotype G5 and G1 had the most negative response to salinity (Figure $3 b$ ). 
Table 4- Change in seedling stem lengths of chickpea genotype with ECi levels

\begin{tabular}{lcccccc}
\hline Genotype & $0 d S / m$ & $6 d S / m$ & $8 d S / m$ & $10 d S / m$ & $12 d S / m$ & $16 d S / m$ \\
\hline G1 & $74.99 \pm 5.84$ & $56.06 \pm 4.04$ & $52.85 \pm 7.61$ & $45.58 \pm 11.18$ & $25.15 \pm 3.38$ & $4.65 \pm 1.51$ \\
G2 & $102.31 \pm 3.76$ & $85.45 \pm 6.87$ & $79.91 \pm 10.62$ & $36.57 \pm 22.53$ & $32.62 \pm 20.91$ & $0.64 \pm 1.12$ \\
G3 & $114.39 \pm 4.15$ & $84.23 \pm 5.77$ & $56.68 \pm 23.36$ & $32.69 \pm 22.63$ & $7.72 \pm 2.86$ & $2.58 \pm 4.46$ \\
G4 & $75.19 \pm 5.54$ & $57.51 \pm 14.14$ & $48.93 \pm 7.58$ & $44.92 \pm 3.75$ & $29.94 \pm 4.90$ & $1.48 \pm 2.06$ \\
G5 & $56.82 \pm 11.02$ & $44.71 \pm 6.10$ & $38.75 \pm 11.28$ & $34.97 \pm 11.03$ & $17.06 \pm 2.34$ & $1.24 \pm 2.16$ \\
G6 & $104.51 \pm 7.65$ & $96.29 \pm 14.72$ & $73.91 \pm 13.82$ & $53.37 \pm 24.60$ & $23.58 \pm 1.03$ & $2.56 \pm 0.34$ \\
G7 & $94.33 \pm 15.23$ & $87.27 \pm 17.26$ & $58.17 \pm 25.66$ & $30.10 \pm 9.81$ & $17.13 \pm 3.22$ & $5.33 \pm 1.53$ \\
G8 & $68.29 \pm 2.13$ & $51.36 \pm 5.21$ & $42.52 \pm 7.81$ & $21.86 \pm 0.98$ & $20.56 \pm 1.71$ & $0.00 \pm 0.00$ \\
G9 & $95.64 \pm 5.73$ & $78.10 \pm 12.53$ & $65.32 \pm 10.98$ & $54.02 \pm 11.44$ & $31.40 \pm 7.35$ & $4.34 \pm 1.33$ \\
G10 & $52.68 \pm 2.34$ & $47.54 \pm 5.82$ & $41.82 \pm 5.16$ & $25.95 \pm 2.63$ & $23.34 \pm 4.59$ & $6.68 \pm 1.29$ \\
G11 & $80.71 \pm 4.49$ & $59.64 \pm 15.25$ & $49.89 \pm 7.98$ & $42.63 \pm 11.62$ & $19.89 \pm 2.35$ & $5.40 \pm 0.36$ \\
Genotype & $* *$ & $* *$ & $\mathrm{NS}$ & $\mathrm{NS}$ & $* *$ & $* *$ \\
Average & 83.62 & 68 & 55.3 & 38.4 & 22.6 & 3.2 \\
Minimum & 52.68 & 44.7 & 38.8 & 21.9 & 7.72 & 0 \\
Maximum & 114.4 & 96.3 & 79.9 & 54 & 32.6 & 6.7 \\
LSD 0.01 & 16.58 & 25.01 & $\mathrm{NS}$ & $\mathrm{NS}$ & 16.73 & 4.29 \\
\hline & & & & & &
\end{tabular}

**: Genotypes are statistically different $(\mathrm{P}<0.01)$

\subsection{Seedling dry weight}

Decreasing seedling dry weights were observed with increasing irrigation water salinity levels (Table 5). In biplot graph (Figure 4b) generated for visual presentation of change in seedling dry weights of the genotypes with ECi levels, salinity treatments were gathered under two groups. The first group included 0, 6, 8 and $10 \mathrm{dS} / \mathrm{m}$ ECi levels and the second group included 12 and 16 $\mathrm{dS} / \mathrm{m}$ ECi levels. 

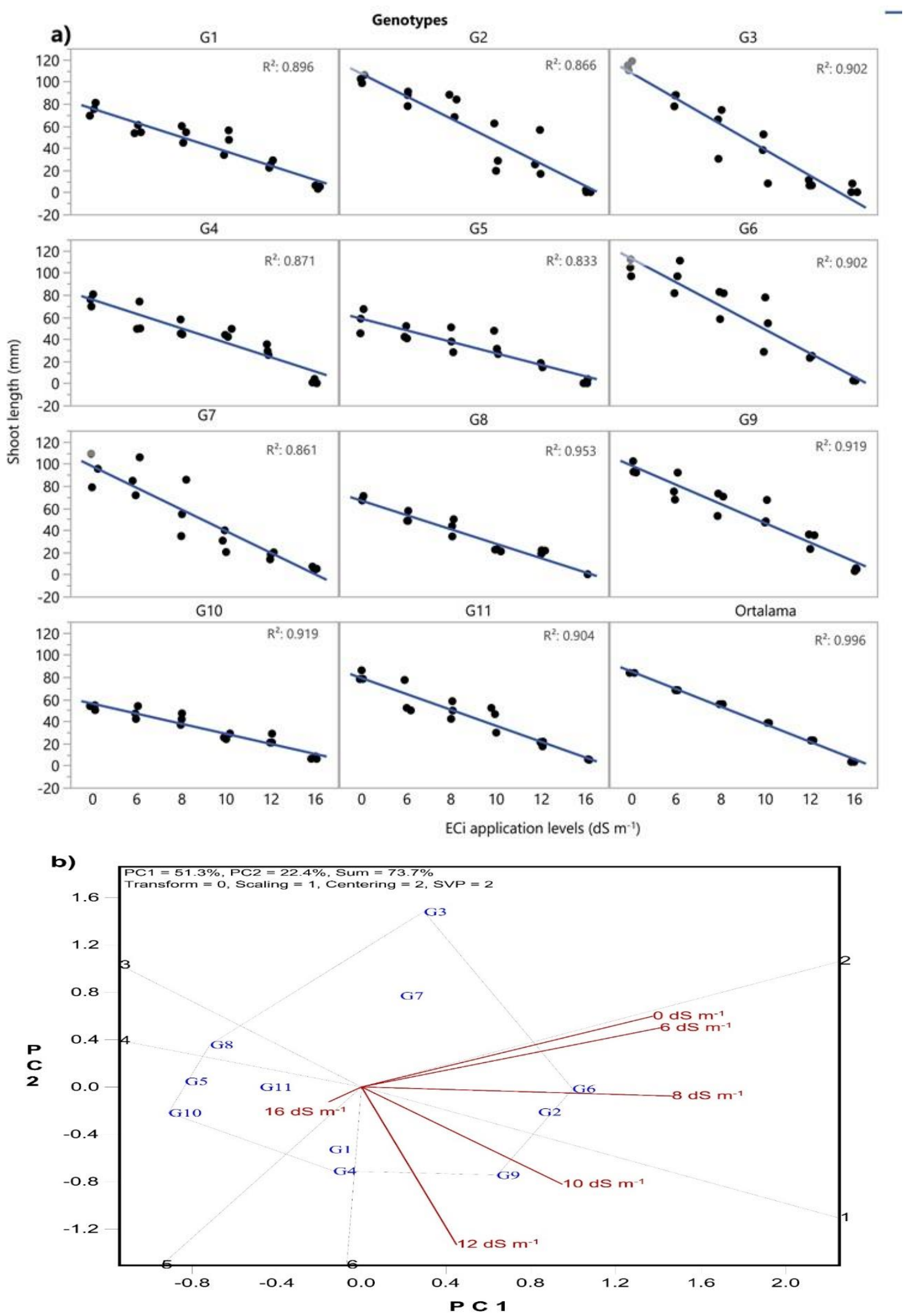

Figure 3- Seedling stem lengths at different ECi levels a) regression b) GGE biplot graph

The greatest seedling dry weight was observed in G4 of the first group and G10 of the second group. These genotypes were placed at diagonals. The greatest decreases in seedling dry weights with ECi levels were observed in G8, G5 and G9 genotypes (Figure 4b). 
Table 5- Change in seedling dry weights of chickpea genotype with ECi levels

\begin{tabular}{|c|c|c|c|c|c|c|}
\hline Genotype & $0 \mathrm{dS} / \mathrm{m}$ & $6 d S / m$ & $8 d S / m$ & $10 \mathrm{dS} / \mathrm{m}$ & $12 \mathrm{dS} / \mathrm{m}$ & $16 \mathrm{dS} / \mathrm{m}$ \\
\hline G1 & $1.13 \pm 0.28$ & $1.09 \pm 0.29$ & $1.04 \pm 0.31$ & $0.87 \pm 0.25$ & $0.70 \pm 0.22$ & $0.27 \pm 0.10$ \\
\hline G2 & $1.57 \pm 0.04$ & $1.34 \pm 0.20$ & $1.05 \pm 0.03$ & $0.83 \pm 0.27$ & $0.61 \pm 0.17$ & $0.22 \pm 0.15$ \\
\hline G3 & $1.06 \pm 0.14$ & $0.84 \pm 0.09$ & $0.76 \pm 0.04$ & $0.71 \pm 0.05$ & $0.63 \pm 0.12$ & $0.36 \pm 0.02$ \\
\hline G4 & $2.41 \pm 0.10$ & $1.59 \pm 0.24$ & $1.40 \pm 0.27$ & $1.27 \pm 0.31$ & $0.97 \pm 0.45$ & $0.40 \pm 0.41$ \\
\hline G5 & $0.74 \pm 0.05$ & $0.71 \pm 0.04$ & $0.49 \pm 0.06$ & $0.44 \pm 0.08$ & $0.38 \pm 0.08$ & $0.33 \pm 0.05$ \\
\hline G6 & $1.12 \pm 0.11$ & $1.00 \pm 0.06$ & $0.93 \pm 0.03$ & $0.78 \pm 0.14$ & $0.59 \pm 0.21$ & $0.47 \pm 0.24$ \\
\hline G7 & $1.23 \pm 0.21$ & $0.97 \pm 0.23$ & $0.87 \pm 0.15$ & $0.67 \pm 0.06$ & $0.50 \pm 0.00$ & $0.30 \pm 0.10$ \\
\hline G8 & $0.41 \pm 0.04$ & $0.32 \pm 0.04$ & $0.30 \pm 0.05$ & $0.25 \pm 0.01$ & $0.18 \pm 0.06$ & $0.00 \pm 0.00$ \\
\hline G9 & $1.57 \pm 0.10$ & $1.03 \pm 0.35$ & $0.84 \pm 0.27$ & $0.73 \pm 0.23$ & $0.55 \pm 0.29$ & $0.13 \pm 0.02$ \\
\hline G10 & $1.72 \pm 0.01$ & $1.59 \pm 0.13$ & $1.29 \pm 0.09$ & $1.16 \pm 0.12$ & $1.00 \pm 0.12$ & $0.71 \pm 0.50$ \\
\hline 11 & $1.12 \pm 0.27$ & $0.91 \pm 0.09$ & $0.83 \pm 0.07$ & $0.73 \pm 0.04$ & $0.64 \pm 0.03$ & $0.39 \pm 0.23$ \\
\hline Genotype & $* *$ & $* *$ & $* *$ & $* *$ & $* *$ & $* *$ \\
\hline Average & 1.28 & 1.04 & 0.89 & 0.77 & 0.61 & 0.33 \\
\hline Minimum & 0.41 & 0.32 & 0.30 & 0.25 & 0.18 & 0.06 \\
\hline Maximum & 2.41 & 1.59 & 1.40 & 1.27 & 1.00 & 0.71 \\
\hline LSD 0.01 & 0.35 & 0.43 & 0.37 & 0.40 & 0.47 & 0.53 \\
\hline
\end{tabular}

In cultivar development studies with breeding methods, different genetic variation sources should be used through modern methods, significant traits should be investigated with the use of proper methods, selection criteria should be developed/specified and characteristics of developed cultivars should be well-defined. 

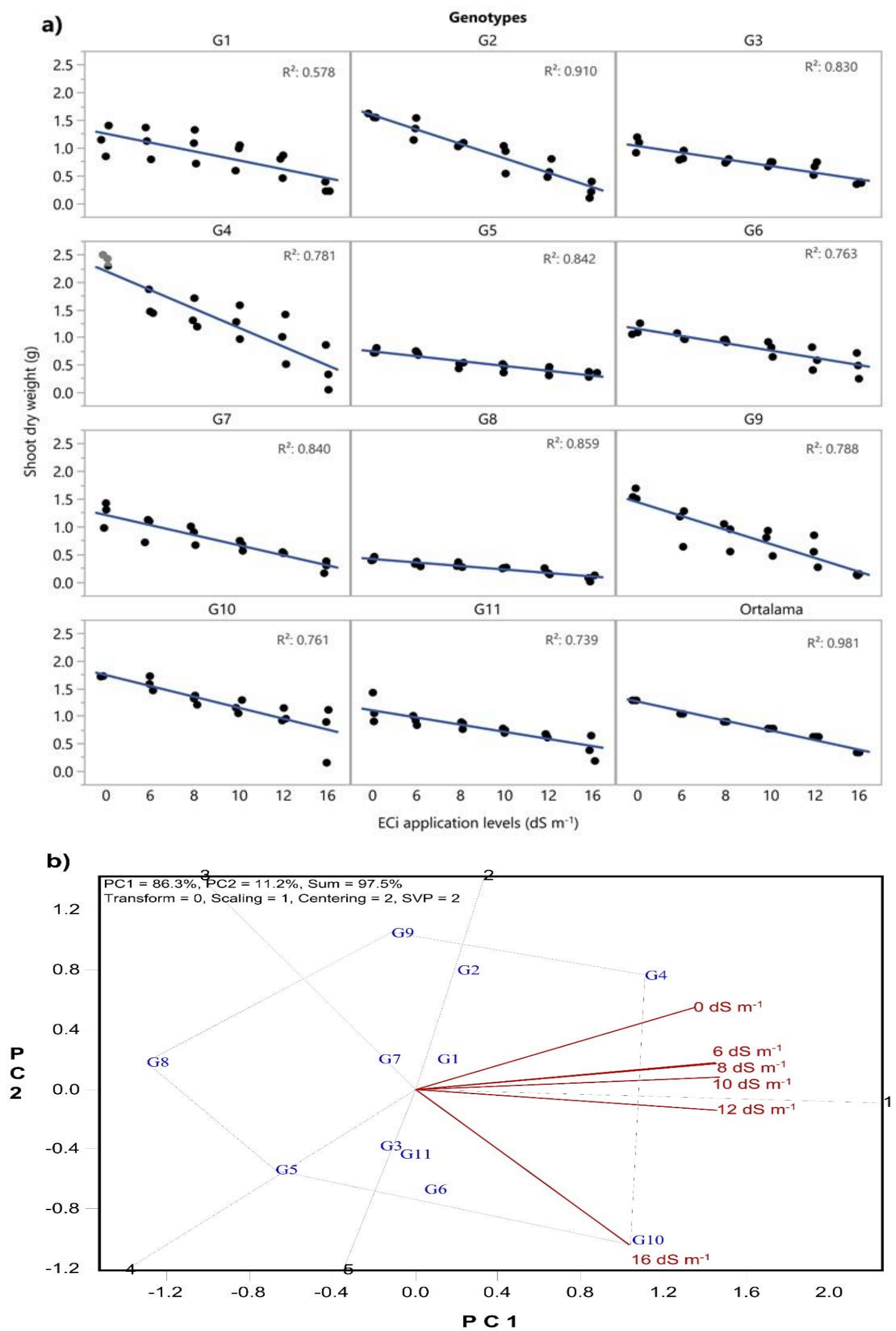

Figure 4- Seedling dry weights at different ECi levels a) regression b) GGE biplot graph

Already limited water resources will get even more deficit in the future. Such deficit nature of water resources will necessitate the use of poor or low-quality waters in irrigations. A sustainable production model should be generated while using these poorquality waters. For sustainable plant production, resistance to stress factors, especially sensitivity/resistance of the plants to water and soil salinity should be determined and threshold salinity values should be identified. Present findings may offer significant information to further breeding studies about salt tolerance of the plants. 
Genotypic differences in germination play an important role in identification of salt tolerance (Saxena et al. 1994). Therefore, seed germination in Petri dishes with saline irrigation water solutions are generally used for rapid identification of plant salt tolerance (Jana \& Slinkard 1976). Previous researchers used petri dishes with different NaCl salt solutions in beans (Goertz \& Coons 1989; Guvenc \& Kantar 1996; Elkoca \& Kantar 2003), sorghum (Esechie 1994), bread wheat (Kirtok et al. 1994; Coskun \& Tas 2017) and different vegetables (Cucci et al. 1994) and identified salt tolerant/resistant cultivars in a short time. Citak \& Toprak (2016) reported chickpea kernel yield was $351 \mathrm{~kg} / \mathrm{da}$ at full irrigation and $281 \mathrm{~kg} / \mathrm{da}$ at deficit irrigation (50\%) treatment. Ozcan et al. (2000) supplemented $500 \mathrm{~g}$ pot soils with $68 \mathrm{mmol} / \mathrm{kg} \mathrm{NaCl}$ to generate salt stress on three different chickpea cultivars under greenhouse conditions and reported that Damla chickpea cultivar had lower dry weight, $\mathrm{Na}$ and $\mathrm{Cl}$ content than the other cultivars under $\mathrm{NaCl}$ salt stress.

Present study revealed that, in the germination tests, besides control treatment $(0 \mathrm{dS} / \mathrm{m})$, five different ECi levels $(6,810,12$ and $16 \mathrm{dS} / \mathrm{m}$ ) were applied. Threshold salinity value for germination was identified as $12 \mathrm{dS} / \mathrm{m}$ based on germination ratios and seedling dry weights, $8 \mathrm{dS} / \mathrm{m}$ based on seedling stem lengths and $10 \mathrm{dS} / \mathrm{m}$ based on seedling root lengths. According to these results, it is understood that chickpeas are quite resistant to salinity.

In terms of germination ratios and seedling dry weights, G4 genotype was identified as the most resistant and G5 was identified as the most sensitive cultivar to irrigation water salinity. The greatest seedling root and stem lengths were obtained from G2 and G4 genotypes. The present findings revealed that G5, G8 and G9 genotypes for germination rate and seedling dry weight, and G5 and G1 genotypes for seedling root length and seedling stem length were more sensitive to salinity.

\section{Conclusions}

The GGB biplot method can be used safely in determining the threshold value of irrigation water salinity in germination tests. Threshold salinity value for germination was identified as $12 \mathrm{dS} / \mathrm{m}$ based on germination ratios and seedling dry weights, $8 \mathrm{dS} / \mathrm{m}$ based on seedling stem lengths and $10 \mathrm{dS} / \mathrm{m}$ based on seedling root lengths. Based on germination ratios and seedling dry weights, Azkan cultivar was identified as the most resistant and Cagatay cultivar was identified as the most sensitive cultivar to irrigation water salinity.

\section{Acknowledgments}

We thank to Canakkale Onsekiz Mart University Scientific Research Coordination Unit. Project number: FBA-2019-2805.

\section{References}

Alkan B B (2011). Biplot Technique in Multivariate Statistical Methods. Ankara University Graduate School of Natural and Applied Sciences Department of Statistics. Ph.D. Thesis. Ankara (Unpublished).

Assouline S, Moller M, Cohen S, Ben-Hur M, Grava A, Narkis K \& Silber A (2006). Soil-plant system response to pulsed drip irrigation and salinity bell pepper case study. Soil Science Society of America Journal 70: 1556-1568. https://doi.org/10.2136/sssaj2005.0365

Atak M, Kaya M , Kaya G, Cikili Y \& Ciftci C Y (2006). Effects of $\mathrm{NaCl}$ on Germination, Seedling Growth and Water Uptake of Triticale. Turk. J. Agric. For 30: 39-47

Bradu D \& Gabriel K R (1978). The Biplot as a Diagnostic Tool for Models of Twoway Tables. Technometrics Vol. 20. 47-68. https://doi.org/10.1080/00401706.1978.10489617

Citak G \& Topak R (2016). The Effect of Different Irrigation Programs on the Yield and Quality of the Chickpea. Selcuk Journal of Agriculture and Food Sciences 3(2): 298-303

Coskun Y \& Tas I (2017). Respons of wheat species to irrigation water salinity. Genetika-Belgrade Vol. 49(2). 435-444. https://doi.org/10.2298/GENSR1702435C

Cucci G, De Caro A, Ciciretti L \& Leoni B (1994). Salinity and seed germination of some vegetable crops. Acta Hortic 362: 305-308. https://doi.org/10.17660/actahortic.1994.362.37

Daigle G \& Rivest L P (1992). A robust biplot. Canadian Journal of Statistics 20(3): 241-255. https://doi.org/10.2307/3315312

Ekiz H, Bagci S A, Yilmaz A, Caglayan N \& Bozoglu S (2000). Determination of salt tolerance degrees of different cereal varieties and lines.

Ministry of Agriculture and Rural Affairs Agricultural Research Gen. Director, Bahri Dağdaş International Winter Wheat Res. Central Manager Publications, no: SR2000-6, 1-59 pp. Konya. (In Turkish)

Elkoca E \& Kantar F (2003). The Effects of Different NaCl Concentrations on Germination and Seedling Growth of Dry Bean (Phaseolus vulgaris L.) Genotypes. Atatürk University Journal of Agricultural Faculty 34(1): 1-8

Esechie H A (1994). Interaction of salinity and temperature on the germination of sorghum. J.Agron. and Crop Sci 172: 194-199. https://doi.org/10.1111/j.1439-037x.1994.tb00166.x

Gabriel K R (1971). The Biplot Graphic Display of Matrices with Application to Principal Component Analysis. Biometrika 58(3): $453-467$. https://doi.org/10.1093/biomet/58.3.453

Gabriel K R \& Odoroff C L (1990). Biplots in Biomedical Research. Statistic in Medicine 9: 469 - 485. https://doi.org/10.1002/sim.4780090502

Gabriel K R (1995). MANOVA Biplots for Two-way Contingency Tables, Recent Advances in Descriptive Multivariate Analysis, Oxford. Clarendon Pres.

Goertz S H \& Coons J M (1989). Germination response of tepary and navy beans to sodium chloride and temperature. Hortsci 24: 923-925

Greenacre M J (1984). Theory and applications of correspondence analysis. Academic Press, London.

Greenacre M J (1993). Biplots in correspondence analysis. Journal of Applied Statistics 20: 251-269 
Guvenc I \& Kantar F (1996). Determination of salt tolerant bean genotypes (Phaseolus vulgaris L.). SDU Journal of Agriculture Faculty 9(11): $144-153$

Jana M K \& Slinkard A E (1976). Screening for salt tolerance in lentil. Lens Newsletter 6: 5-27

Jiang J, Huo Z, Feng S \& Zhanga C (2012). Effect of irrigation amount and water salinity on water consumption and water productivity of spring wheat in Northwest China. Field Crops Research 137: 78-88. https://doi.org/10.1016/j.fcr.2012.08.019

Kirtok Y, Veli S, Tukel S, Duzenli S \& Kilinc M (1994). Evaluation of salinity stress on germination characteristics and seedling growth of 3 bread wheats (Triticum aestivum L.). Field Crops Congress 25-29 April 1994 Izmir. (In Turkish)

Koyuncu N (2008). Determination of In Vitro Salt Tolerance in Turkish Common and Durum Wheat (Triticum spp.) cultivars. Ankara University Graduate School of Natural and Applied Sciences Department of Field Crops. Ph.D. Thesis. Ankara. (Unpublished)

Kusvuran A (2015). The effects of salt stress on the germination and antioxidative enzyme activity of Hungarian vetch (Vicia pannonica Crantz.) varieties. Agricultural Research Communication Centre 38(1): 51-59. https://doi.org/10.5958/0976-0571.2015.00009.0

Letey J \& Feng G L (2007). Dynamic versus steady-state approaches to evaluate irrigation management of saline waters. Agricultural Water Management 91: 1-10. https://doi.org/10.1016/j.agwat.2007.02.014

Min W, Hou Z, Ma L, Zhang W, Ru S \& Ye J (2014). Effects of water salinity and N application rate on water- and N-use efficiency of cotton under drip irrigation. $J$ Arid Land (2014) 6(4): 454-467. https://doi.org/10.1007/s40333-013-0250-3

Munns R (2002). Comparative physiology of salt and water stress. Plant, Cell and Environment 25: 239-250. https://doi.org/10.1046/j.00168025.2001.00808.x

Ojeda M M \& Juarez-Cerrillo S F (1996). Biplot display for diagnostic in a two-level regression model for growth curve analysis. Computational Statistics and Data Analysis, Vol. 22, pp. 583-597. https://doi.org/10.1016/0167-9473(96)00013-8

Okhovatian-Ardakani A R, Mehrabanian M, Dehghani F \& Akbarzadeh A (2010). Salt tolerance evaluation and relative comparison in cuttings of different pomegranate cultivars. Plant Soil Environ 56(4): 176-185. https://doi.org/10.17221/158/2009-pse

Ozcan H, Turan M A, Koc O, Cikili Y \& Taban S (2000). Growth and Variations in Proline, Sodium, Chloride, Phosphorus and Potassium Concentrations of Chickpea (Cicer arietinum L. cvs.) Varieties Under Salinity Stress. Turk J Agric For 24: 649-654

Pereira L S, Oweis T \& Zairi A (2002). Irrigation management under water scarcity. Agricultural Water Management 57: 175-206. https://doi.org/10.1016/s0378-3774(02)00075-6

Peykanpour E, Ghehsareh A M, Fallahzade J \& Najarian M (2016). Interactive effects of salinity and ozonated water on yield components of cucumber. Plant Soil Environ 62(8): 361-366

Saxena N P, Saxena M C, Ruckenbauer P, Rana RS, El-Fouly M M \& Shabana R (1994). Screening techniques and sources of tolerance to salinity and mineral nutrient imbalances in cool season food legumes. Euphytica 73: 85-93. https://doi.org/10.1007/978-94-011-0798-3_27

Sparks R, Adolphson A \& Phatak A (1997). Multivariate Process Monitoring Using the Dynamic Biplot. International Statistical Review 65(3): 325-349. https://doi.org/10.2307/1403375

Sozen O \& Karadavut U 2018. Determination of Genotype x Environment Interactions of Some Chickpea (Cicer arietinum L.) Genotypes by Using Different Stability Methods. Journal of Agricultural Sciences 24(2018) 431-438. https://doi.org/10.15832/ankutbd.490930

Wang W B, Kim Y H, Lee H S, Kim K Y, Deng X P \& Kwak S S (2009). Analysis of antioxidant enzyme activity during germination of alfalfa under salt and drought stresses. Plant Physiology and Bioch 47(7): 570-577. https://doi.org/10.1016/j.plaphy.2009.02.009

Yan W (2014). Crop variety trials. Data management and analysis. Wiley-Blackwell, Hoboken, New Jersey, 349 p.

Yeo A R, Yeo M E, Flowers S A \& Flowers T J (1990). Screening of rice (Oryza sativa L.) genotypes for physiological characters contributing to salinity resistance and their relationship to overall performance. Theoretical and Applied Genetics 79: 377-384. https://doi.org/10.1007/bf01186082

Yurtseven E, Colak M S, Ozturk A \& Ozturk H S 2018. Drainage water salt load variations related to the salinity and leaching ratios of irrigation water. Journal of Agricultural Sciences 24(2018): 394-402. https://doi.org/10.15832/ankutbd.456667

(C) 2022 by the author(s). Published by Ankara University, Faculty of Agriculture, Ankara, Turkey. This is an Open Access article distributed under the terms and conditions of the Creative Commons Attribution (CC BY) license (http://creativecommons.org/licenses/by/4.0/), which permits unrestricted use, distribution, and reproduction in any medium, provided the original work is properly cited. 